\title{
PENERAPAN MEDIA VCD (VIDEO COMPACT DISC) INTERAKTIF UNTUK MENINGKATKAN HASIL BELAJAR SISWA KONSEP LAJU REAKSI DI KELAS XI SMA NEGERI 3 LEIHITU
}

\author{
N. S. B. Mamang ${ }^{1^{*}}$, Sunarti ${ }^{1}$, F. A. Hamid ${ }^{1}$ \\ ${ }^{1}$ Departement of Chemistry -FKIP, Pattimura University Ambon \\ "mamangn2@gmail.com
}

\begin{abstract}
A research had been done by using interactive VCD (Video Compact Disc) as a media to increase students' learning outcome on the concept of reaction rate at XI grade of SMA Negeri 3 Leihitu. The data collection was done through test by using pre and posttest and observation by using affective and psychomotor observation paper. The findings showed that all of the students could achieve the minimal completeness criteria (KKM). It showed the aspects of cognitive, affective and psychomotor which had been achieved by the students such as the final score obtained that 9 students $(34,62 \%)$ with very good qualification, 13 students $(50 \%)$ with good qualification and 4 students $(15,38 \%)$ with enough qualification. The collected data achievement $\mathrm{N}$-gain showed that 25 students $(96,15 \%)$ achieved high $N$-gain category and 1 students $(3,85 \%)$ achieved medium $N$ gain category with the $\mathrm{N}$-gain achievement criteria was 0,84 . Thus, the application of interactive VCD (Video Compact Disc) as a media had been proved to increase the students' learning outcome on the concept of reaction rate at XI grade of SMA Negeri 3 Leihitu.
\end{abstract}

Keywords: Interactive VCD (Video Compact Disc), Learning outcome, Reaction Rate.

\section{ABSTRAK}

Telah dilakukan penelitian dengan menggunakan media VCD (Video Compact Disc) interaktif pada konsep laju reaksi untuk meningkatkan hasil belajar siswa kelas XI SMA Negeri 3 Leihitu. Pengumpulan data dilakukan melalui tes menggunakan lembar tes awal dan akhir serta observasi menggunakan lembar pengamatan afektif dan psikomotor. Hasil penelitian menunjukan bahwa seluruh siswa dapat mencapai kriteria ketuntasan minimal (KKM) yaitu pada aspek kognitif, afektif dan psikomotor dengan nilai akhir yang diperoleh adalah kualifikasi sangat baik 9 siswa (34,62\%), kualifikasi baik 13 siswa (50\%) dan kualifikasi cukup 4 siswa (15,38\%). Data pencapaian $\mathrm{N}$-gain yang diperoleh yaitu 25 siswa $(96,15 \%)$ mencapai kategori $N$-gain tinggi dan 1 siswa $(3,85 \%)$ mencapai $N$-gain sedang, data pencapaian dengan kriteria $N$-gain yang diperoleh adalah 0,84 . Dengan demikian penerapan media VCD interaktif dinyatakan berhasil meningkatkan hasil belajar siswa konsep laju reaksi di kelas XI SMA Negeri 3 Leihitu.

Kata Kunci: VCD (Video Compact Disc) interaktif, Hasil Belajar, Laju Reaksi.

\section{PENDAHULUAN}

Masalah umum dalam pendidikan kimia adalah hasil belajar yang rendah. Rendahnya hasil belajar ini dipengaruhi banyak faktor. Salah satunya adalah siswa menganggap pelajaran kimia merupakan pelajaran yang sulit sehingga siswa merasa kurang mampu mempelajarinya. Kebanyakan konsep-konsep dalam ilmu kimia merupakan konsep atau materi yang abstrak dan kompleks sehingga untuk mengatasi hal tersebut, materi perlu ditunjukkan dalam bentuk yang lebih konkret, misalnya dengan percobaan atau media tertentu (Gusbandono dkk., 2013: 102). 
Upaya yang telah dilakukan untuk meningkatkan hasil belajar siswa adalah dengan menggunakan multimedia dalam pembelajaran. Hendrisakti, dkk (2013: 24) mengungkapkan bahwa terdapat perbedaan kompetensi kimia antara siswa yang mengikuti pembelajaran dengan media papan tulis, multimedia noninteraktif dan multimedia interaktif. Pembelajaran kimia menggunakan media multimedia interaktif lebih baik dibandingkan dengan pembelajaran kimia yang menggunakan media papan tulis.

Hasil wawancara dengan salah seorang guru mata pelajaran kimia di SMA Negeri 3 Leihitu, menunjukkan bahwa terdapat $50 \%$ siswa yang mencapi ketuntasan dan $50 \%$ siswa lainnya tidak mencapai ketuntasan. Hal ini disebabkan karena terdapat beberapa kendala dalam pelaksanaan proses pembelajaran. Kendala tersebut adalah kurangnya bahan ajar dan materi laju reaksi sulit dipahami. Siswa kurang aktif belajar karena guru jarang mendesain media atau model pembelajaran yang sesuai dengan kemampuan siswa di kelas, dimana pembelajaran lebih terpusat pada guru. Hal ini menyebabkan hasil belajar siswa kurang memuaskan.

Materi laju reaksi diajarkan pada kelas XI semester ganjil, banyak mengkaji konsep-konsep tentang laju suatu reaksi kimia dan juga menggunakan rumus dalam menentukan persamaan laju yang abstrak. Oleh karena itu dibutuhkan media pembelajaran interaktif yang dapat memvisualkan hal-hal tersebut ke hadapan siswa dalam bentuk sederhana dan mudah dimengerti baik dalam bentuk teks, animasi, video, maupun gambar. Penyajian materi dengan cara tersebut akan mempermudah siswa dalam memahaminya. Media ini juga dilengkapi dengan banyak latihan dan video cara menyelesaikan suatu soal sehingga akan sangat membantu siswa dalam memahami materi pelajaran tersebut. Salah satu multimedia yang dapat digunakan adalah VCD (Video Compact Disc) Interaktif.

Berdasarkan hasil penelitian sebelumnya oleh Noer (2014) tentang Peningkatan Proses Belajar Kimia Melalui Pemanfaatan VCD di SMA Muhammadiyah Pekan Baru menunjukan peningkatan hasil evaluasi belajar, dimana nilai rata-rata siswa dengan pemanfaatan program VCD sebesar 74,23 dengan ketuntasan belajar siswa 71,16 \%. Sedangkan nilai rata-rata siswa tanpa VCD sebesar 62,20 dan ketuntasan belajar siswa 4,30\%.

Dewi, dkk. (2016) telah meneliti tentang Penerapan Model Pembelajaran Team Games Tournament (TGT) disertai Video Compact Disc (VCD) dan Teka Teki Silang (TTS) Untuk Meningkatkan Minat dan Prestasi Belajar Kimia Pada Materi Konsep Materi dan Perubahannya menunjukan bahwa terdapat perbedaan peningkatan minat dan hasil belajar pada materi pokok konsep materi dan perubahannya sebelum dan sesudah pelaksanaan tindakan. Dimana sebelum pelaksanaan tindakan, hasil capaian aspek kognitif, afektif dan minat siswa sebesar 34,38\%, $73,17 \%, 68,78 \%$. Sedangkan setelah pelaksanaan tindakan, hasil capaian aspek kognitif, afektif dan minat siswa meningkat menjadi $90,62 \%, 78,33 \%$ dan $75,05 \%$.

Berdasarkan uraian di atas, maka dianggap penting untuk dilakukan penelitian mengenai "Penerapan Media VCD (Video Compact Disc) Interaktif terhadap Hasil Belajar Siswa pada Konsep Laju Reaksi di Kelas XI SMA Negeri 3 Leihitu".

\section{METODE PENELITIAN}

Tipe penelitian yang digunakan adalah eksperimen semu dan analisis deskriptif yakni menggambarkan gejala, peristiwa atau kejadian yang terjadi pada saat penelitian dengan menggunakan media VCD (Emzir, 2011).

Sampel dalam penelitian ini adalah siswa kelas XI IPA SMA Negeri 3 Leihitu yang berjumlah 26 siswa. Variabel yang digunakan dalam penelitian ini adalah variabel tunggal, yakni hasil belajar siswa pada konsep laju reaksi dengan menggunakan media pembelajaran VCD interaktif Istrumen penelitian yang digunakan yaitu Instrument test berupa tes awal dan tes akhir siswa, sedangkan 
instrument non test berupa lembar observasi dan lembar kerja siswa. Teknik pengumpulan data yang digunakan dalam penelitian ini adalah menggunakan teknik test dan non test.

\section{HASIL PENELITIAN}

\section{A. Hasil Tes Kemampuan Awal Siswa}

Tabel 1. Data Pencapaian Siswa Hasil Tes Awal

\begin{tabular}{cccc}
\hline Nilai & Frekuensi & $\begin{array}{c}\text { Frekuensi } \\
\text { Relatif }(\%)\end{array}$ & Kualifikasi \\
\hline $90-100$ & - & - & Sangat baik \\
$80-89$ & - & - & Baik \\
$73-79$ & - & - & Cukup \\
$<73$ & 26 & 100 & Gagal \\
Jumlah & 26 & 100 & \\
\hline
\end{tabular}

Berdasarkan Tabel 1, dapat dilihat bahwa 26 siswa (100\%) berada pada kualifikasi gagal atau belum mencapai KKM. Hal ini menunjukkan bahwa seluruh siswa belum menguasai konsep laju reaksi sehingga ketuntasan belajar belum tercapai atau dikategorikan gagal karena hasil yang diperoleh $<73$, dengan nilai tes awal tertinggi adalah 30,55 dan terendah adalah 4,16 . Hal ini menunjukkan bahwa secara keseluruhan siswa masih memiliki pengetahuan yang minim tentang laju reaksi. Selain itu, dari hasil tes awal juga diperoleh gambaran bahwa seluruh materi laju reaksi harus mendapat prioritas dalam proses pembelajaran.

Ketidakmampuan siswa dalam menjawab soal-soal pada tes awal disebabkan karena materi laju reaksi belum pernah diajarkan kepada siswa sehingga pengetahuan awal siswa terhadap materi laju reaksi masih minim dan siswa tidak memiliki kesiapan yang cukup sebelum mengikuti proses pembelajaran. Hal ini sejalan dengan pernyataan Suryosubroto (2009) bahwa ketidakmampuan siswa dalam menjawab soal tes awal dengan nilai yang diperoleh adalah 0 atau hanya sedikit yang menjawab dengan benar, hal ini dapat dimengerti karena materi tersebut belum pernah diberikan oleh guru. Oleh karena itu keseluruhan indikator perlu menjadi perhatian guru pada saat proses pembelajaran berlangsung dengan menggunakan media pembelajaran VCD interaktif.

\section{B. Hasil Belajar Afektif Siswa}

Tabel 2. Data Pencapaian Hasil Belajar Afektif Siswa

\begin{tabular}{cccccccc}
\hline \multirow{2}{*}{ Nilai } & \multicolumn{2}{c}{ Pert. I } & \multicolumn{2}{c}{ Pert. II } & \multicolumn{2}{c}{ Pert. III } & \multirow{2}{*}{ Kualifikasi } \\
\cline { 2 - 6 } & Fk & $\begin{array}{c}\text { Fk } \\
\text { relatif\% }\end{array}$ & Fk & $\begin{array}{c}\text { Fk } \\
\text { relatif } \%\end{array}$ & Fk & $\begin{array}{c}\text { Fk } \\
\text { relatif } \\
\%\end{array}$ & \\
\hline $90-100$ & 10 & 38,46 & 14 & 53,85 & 10 & 38,46 & Sangat baik \\
$80-89$ & 12 & 46,15 & 12 & 46,15 & 14 & 53,85 & Baik \\
$73-79$ & 4 & 15,39 & - & & 2 & 7,69 & Cukup \\
$<73$ & - & - & - & - & - & - & Kurang/gagal \\
Jumlah & 26 & 100 & 26 & 100 & 26 & 100 & \\
\hline *Pert = Pertemuan & Fk = Frekuensi & & & & &
\end{tabular}


Pada aspek ini menunjukkan bahwa tidak semua siswa memenuhi kriteria penilaian afektif atau tidak semua siswa memberikan respon yang baik selama proses pembelajaran berlangsung. Hal ini disebabkan karena dalam proses penilaian afektif ada siswa yang tidak memenuhi aspek baik yang dinilai dalam rubrik penilaian afektif.

Pada pertemuan I, terdapat 4 siswa $(15,39 \%)$ berada pada kualifikasi cukup, hal ini dikarenakan siswa tersebut ada yang tidak serius, kurang kerjasama dan kurang disiplin dalam mengerjakan soal pada LKS sehingga siswa kurang aktif dalam kelompok. Oleh karena itu, selama proses pembelajaran guru tidak hanya memberikan materi dan menilai siswa tetapi juga memotivasi siswa.

Pada pertemuan II, terjadi peningkatan dari pertemuan pertama. Hal ini terjadi karena dalam proses pembelajaran berlangsung, siswa begitu antusias dan bersemangat dalam memperhatikan eksperimen yang ditayangkan lewat VCD. VCD sebagai media audiovisual dapat memperlihatkan secara lebih nyata tentang fenomena yang ada dalam ilmu kimia. Visualisasi yang lebih nyata sangat mendukung pemahaman siswa dalam proses pembelajaran dan siswa juga mendapatkan variasi dalam proses belajar mereka. Seperti teori tumbukan dari hal-hal yang paling abstrak sampai pada hal-hal yang dianggap konkrit.

Pada pertemuan III, 2 siswa berada pada kualifikasi cukup. Hal ini dikarenakan pada proses pembelajaran siswa mulai merasa bosan dengan melihat indikator yang akan dipelajari. Dengan indikator pada pertemuan III tingkat kesukaraannya lebih tinggi dibandingkan dengan indikator pada pertemuan I dan II. Kenyataan ini sejalan dengan pendapat yang dikemukakan oleh Martini (2006) bahwa kemampuan afektif siswa berorientasi pada faktor emosional yang menunjukkan penerimaan dan penolakan terhadap sesuatu, sehingga dalam proses pembelajaran ada beberapa siswa yang kurang meresponi aspek-aspek yang dinilai.

\section{Hasil Belajar Psikomotor Siswa}

Tabel 3. Data Pencapaian Hasil Belajar Psikomotor Siswa

\begin{tabular}{|c|c|c|c|c|c|c|c|}
\hline \multirow[b]{2}{*}{ Nilai } & \multicolumn{2}{|c|}{ Pert. I } & \multicolumn{2}{|c|}{ Pert. II } & \multicolumn{2}{|c|}{ Pert. III } & \multirow[b]{2}{*}{ Kualifikasi } \\
\hline & Fk & $\begin{array}{c}\text { Fk relatif } \\
\%\end{array}$ & Fk & $\begin{array}{c}\mathrm{Fk} \\
\text { relatif \% }\end{array}$ & $\mathrm{Fk}$ & $\begin{array}{c}\text { Fk relatif } \\
\%\end{array}$ & \\
\hline $90-100$ & 9 & 34,62 & 12 & 46,15 & 10 & 38,46 & Sangat baik \\
\hline $80-89$ & 15 & 57,69 & 14 & 53,85 & 12 & 46,15 & Baik \\
\hline 70-79 & 2 & 7,69 & - & - & 4 & 15,38 & Cukup \\
\hline$<70$ & - & - & - & - & - & - & Kurang/gagal \\
\hline Jumlah & 26 & 100 & 26 & 100 & 26 & 100 & \\
\hline
\end{tabular}

${ }^{*}$ Pert $=$ Pertemuan $\quad F k=$ Frekuensi

Pada aspek psikomotor yang dinilai menunjukkan bahwa pada pertemuan I, persentasi siswa dengan kualifikasi sangat baik lebih rendah dibandingkan pertemuan II dan III. Hal ini disebabkan karena beberapa siswa masih belum bisa beradaptasi dengan media VCD yang ditampilkan. Siswa masih cenderung asing dengan media yang dikenalkan oleh guru. Sedangkan pada kualifikasi cukup pada pertemuan I jauh lebih banyak dibandingkan pertemuan II, yang disebabkan oleh kurang termotivasinya siswa meskipun adanya penggunaan media. Oleh karena itu, guru diharapkan memperkenalkan media dengan pendekatan yang lebih efesien terlebih dahulu.

Pada aspek psikomotor pertemuan II terjadi peningkatan dari kualifikasi sangat baik 9 siswa $(34,62 \%)$ menjadi 12 siswa (46,15\%). Peningkatan ini diakibatkan karena penggunaan media pembelajaran dalam proses belajar mengajar mempunyai nilai-nilai yang membangkitkan motivasi dan merangsang siswa untuk belajar. Dimana media VCD ini merupakan gabungan konsep pembelajaran dengan teknologi audio visual yang mampu menghasilkan animasi gerak dan suara 
yang dapat dimanfaatkan siswa dalam belajar. Media dapat menyajikan materi yang lebih menarik yang digunakan untuk merekam, menyimpan, dan merekonstruksi suatu peristiwa atau objek kemudian dianalisis dan dikritik oleh siswa, baik secara perorangan maupun kelompok, tidak monoton dan memudahkan penyampaian serta mampu meningkatkan motivasi belajar siswa.

Pada aspek psikomotor pertemuan III terjadi penurunan dari kualifikasi sangat baik 12 siswa $(46,15 \%)$ menjadi 10 siswa $(38,46 \%)$ dan terjadinya peningkatan jumlah siswa pada kualfikasi cukup. Hal ini disebabkan karena indikator yang dipelajari memiliki tingkat kesukaran yang lebih tinggi dari pertemuan sebelumnya. Tingkat kesukaran yang tinggi menyebabkan siswa kurang mampu dalam memberikan penjelasan kepada teman maupun menanggapi pertanyaan atau pendapat dari teman yang lain.

\section{Hasil Belajar Kognitif}

Tabel 4. Data Pencapaian Hasil Belajar Kognitif Siswa Pada LKS

\begin{tabular}{|c|c|c|c|c|c|c|c|}
\hline \multirow[b]{2}{*}{ Nilai } & \multicolumn{2}{|c|}{ Pert. I } & \multicolumn{2}{|c|}{ Pert. II } & \multicolumn{2}{|c|}{ Pert. III } & \multirow[b]{2}{*}{ Kualifikasi } \\
\hline & $\mathrm{Fk}$ & $\begin{array}{c}\text { Fk relatif } \\
\%\end{array}$ & $\mathrm{Fk}$ & $\begin{array}{c}\text { Fk relatif } \\
\%\end{array}$ & $\mathrm{Fk}$ & $\begin{array}{c}\text { Fk relatif } \\
\%\end{array}$ & \\
\hline $90-100$ & 13 & 50 & 17 & 65,38 & 9 & 34,62 & Sangat baik \\
\hline $80-89$ & 13 & 50 & 9 & 34,62 & 13 & 50 & Baik \\
\hline $73-79$ & - & - & - & - & 4 & 15,38 & Cukup \\
\hline$<73$ & - & - & - & - & - & - & Kurang/gagal \\
\hline Jumlah & 26 & 100 & 26 & 100 & 26 & 100 & \\
\hline
\end{tabular}

Pada LKS pertemuan I, data aspek kognitif menunjukkan bahwa semua siswa berhasil memenuhi kriteria penilaian walaupun dengan kualifikasi yang berbeda-beda. Siswa yang memiliki kualifikasi sangat baik dan baik dikarenakan dalam proses pembelajaran berlangsung menunjukkan keseriusan dalam memperhatikan penjelasan guru, mampu dalam menganalisis soal dengan baik dan memiliki kerjasama yang baik meskipun beberapa siswa pada aspek psikomotor tidak menunjukkan respon yang baik.

Pada LKS pertemuan II, hasil belajar kognitif pada Tabel 4 menunjukkan bahwa terjadi peningkatan pada kualifikasi sangat baik dan tidak adanya siswa pada kualifikasi cukup maupun gagal. Hal ini dikarenakan indikator pada pertemuan II merupakan materi lanjutan bertahap dari pertemuan satu yang berisi lanjutan faktor-faktor yang mempengaruhi laju reaksi (teori tumbukan).

Pada LKS pertemuan III, hasil belajar kognitif dapat dilihat pada Tabel 4, menunjukkan bahwa terjadi penurunan pada kualifikasi sangat baik, karena indikator yang dipelajari memiliki tingkat kesulitan lebih tinggi. Tingkat kesulitan yang tinggi dikarenakan banyaknya perhitungan dibandingkan indikator pada pertemuan I dan II. Indikator-indikator yang sulit menyebabkan Kesulitan belajar yang dikaitkan dengan kegagalan siswa mencapai prestasi akademik (Husamah, dkk, 2018). Sedangkan pada kualifikasi baik terjadi peningkatan, dikarenakan pada saat guru menjelaskan siswa serius dalam memperhatikan. Selain itu juga adanya kerjasama kelompok dalam menyelesaikan soal-soal yang tertera pada LKS, siswa juga mampu dalam menganalisis soal misalnya untuk menentukan orde total berdasarkan orde reaksi yang telah ditentukan siswa sebelumnya. Sedangkan 4 siswa $(15,38)$ berada pada kualifikasi cukup dikarenakan mereka kurang mampu dalam menganalisis soal, memiliki kemampuan matematis yang masih rendah dalam menentukan tetapan laju reaksi, dan kurang kerjasama dalam kelompok.

Dari penelitian ini dapat dilihat suatu hubungan yang erat antara penilaian aspek afektif, psikomotor dan kognitif dimana setiap aspek saling mempengaruhi satu dengan yang lain. Arif, dkk (2013) menyatakan bahwa keberhasilan siswa pada aspek afektif menjadi faktor penunjang bagi 
keberhasilan pembelajaran pada aspek kognitif. Dengan demikian prestasi belajar siswa pada aspek afektif yang tinggi dapat diikuti dengan hasil belajar aspek psikomotor dan aspek kognitif yang tinggi pula karena siswa memeiliki minat dan sikap yang positif saat proses pembelajaran berlangsung.

\section{E. Hasil Belajar Tes Akhir}

Tabel 5. Data Pencapaian Siswa Hasil Tes Akhir

\begin{tabular}{cccc}
\hline Nilai & Frekuensi & $\begin{array}{c}\text { Frekuensi } \\
\text { Relatif (\%) }\end{array}$ & Kualifikasi \\
\hline $90-100$ & 9 & 34,62 & Sangat baik \\
$80-89$ & 13 & 50 & Baik \\
$70-79$ & 4 & 15,38 & Cukup \\
$<70$ & - & - & Kurang/Gagal \\
Jumlah & 26 & 100 & \\
\hline
\end{tabular}

Data pada Tabel 5. menunjukkan bahwa kemampuan siswa pada tes akhir adalah 9 siswa berada pada kualifikasi sangat baik. Hal ini dikarenakan dalam proses pembelajaran siswa sangat serius dan termotivasi dalam belajar sehingga dalam penyelesaian soal dapat mengerjakan dengan benar. Sedangkan 13 siswa berada pada kualifikasi baik dikarenakan siswa berhasil menyelesaikan soal setiap indikator tetapi ada beberapa penyelesaian yang dikerjakan kurang tepat dan 4 siswa berada pada kualifikasi cukup dikarenakan dalam proses penyelesaian soal, ada soal yang dikerjakan tidak sampai hasil akhir misalnya pada indikator menentukan orde dan waktu reaksi dengan soal menentukan tetapan laju reaksi dan ada beberapa soal yang dijawab kurang tepat.

Penggunaan media VCD dalam pembelajaran memiliki kualitas dan peran yang baik sehingga dihasilkan nilai yang sangat tinggi. Media yang dipadukan dengan audio dan visual digunakan dalam pembelajaran yang aktif, kreatif, tidak membosankan dan menyenangkan sehingga pada akhirnya diperoleh kondisi kelas yang termotivasi, aktivitas yang tinggi serta hasil belajar yang memuaskan (Novita, 2017).

Keberhasilan siswa mencapai ketuntasan belajar dalam penelitian ini dikarenakan bimbingan guru yang terarah dalam melaksanakan pembelajaran menggunakan media VCD interaktif yang sekaligus telah membangkitkan semangat belajar sehingga konsentrasi siswa penuh pada pembelajaran yang dilaksanakan. Dengan demikian, penggunaan media VCD interaktif dalam pembelajaran efektif dalam mencapai ketuntasan belajar siswa.

\section{F. Hasil Data N-Gain}

Normalized gain ( $N$-gain) adalah selisih antara tes awal dan tes akhir dibagi dengan kenaikan skor maksimum.

Tabel 6. Data Pencapaian N-Gain

\begin{tabular}{cccc}
\hline Interval & Frekuensi & $\begin{array}{c}\text { Frekuensi } \\
\text { Relatif (\%) }\end{array}$ & Kategori \\
\hline $\mathrm{g}>0,7$ & 25 & 96,15 & Tinggi \\
$0,3 \leq \mathrm{g} \leq 0,7$ & 1 & 3,85 & Sedang \\
$\mathrm{g}<0,3$ & - & - & Rendah \\
Jumlah & 26 & 100 & \\
\hline
\end{tabular}


Data pada Tabel 6. menunjukkan semua siswa mengalami peningkatan hasil belajar dengan kriteria pencapaian $\mathrm{N}$-gain rata-rata adalah 0,84 . Hal ini dibuktikan dalam proses pembelajaran siswa lebih banyak mengerjakan soal-soal latihan yang terdapat dalam lembar kerja siswa (LKS) sehingga siswa dapat menguasai konsep secara mendalam. Selain itu, kemampuan afektif dan keterampilan siswa dalam proses pembelajaran juga sangat baik dan telah mencapai kriteria ketuntasan minimal (KKM) meskipun dengan kualifikasi yang berbeda sehingga diperoleh hasil $N$ gainnya sangat baik dengan kategori gain tinggi. Hal ini sejalan dengan Mergendoller dalam Nuraeni (2010) menyatakan bahwa suatu pembelajaran dikatakan efektif apabila adanya perbedaan yang signifikan secara statistik terhadap hasil belajar siswa yang ditunjukkan dengan peningkatan nilai tes awal dan tes akhir siswa.

\section{KESIMPULAN}

Berdasarkan hasil penelitian yang diperoleh dapat disimpulkan bahwa setelah proses pembelajaran menggunakan media VCD interaktif konsep laju reaksi menunjukan semua siswa dapat mencapai hasil ketuntasan dengan hasil tes akhir adalah 9 siswa $(34,62 \%)$ kualifikasi sangat baik, 13 siswa (50\%) kualifikasi baik, dan 4 siswa (15,38\%) kualifikasi cukup. Dengan pencapaian $\mathrm{N}$-gain yang diperoleh adalah 0,84 . Dengan demikian penerapan media VCD (Video Compact Disc) interaktif dinyatakan berhasil meningkatkan hasil belajar siswa konsep laju reaksi di kelas XI SMA Negeri 3 Leihitu.

\section{DAFTAR PUSTAKA}

Arif, S. S., Rahardjo, R., Haryono, A. (2013). Media Pendidikan: Pengertian, Pengembangan dan pemanfaatan. Jakarta: PT Raja Grafindo Persada

Emzir. (2011). Metodologi Penelitian Pendidikan: Kuantitatif \& Kualitatif (Ed. 1, cet, 5). Jakarta: Rajawali Pers.

Hendrisakti, H., Damris, M., Asrial, A. (2013). Pengaruh Penggunaan Multimedia Interaktif, Multimedia Noninteraktif dan Minat Belajar terhadap Kompetensi Kimia Siswa MAN Cendekita Jambi. Jurnal Edu-Sains. 1(2),24

Gusbandono, T., Sukardjo, J. S., Utomo, S. B., (2013). Pengaruh Metode Pembelajaran Kooperatif Student Team Achievement Divvision (STAD) Dilengkapi Media Animasi Macro Media Flash dan Plastisin Terhadap Prestasi Belajar Siswa Pada Pokok Bahasan Ikatan Kimia Kelas X Semester 1 SMA Negeri 1 Sambung Macan Tahun Pelajaran 2012/2013. Program Studi Pendidikan Kimia, PMIPA, FKIP, UNS, Surakarta, Indonesia. Jurnal Pendidikan Kimia. 102-109,2337-9995.

Martini, J. (2006). Perkembangan Dan Pengembangan Anak. Jakarat: Gramedia

Novita, P. (2017). Pengaruh pemanfaatan media VCD Terhadap Hasil Belajar Siswa Pada Materi Koloid di Kelas XI SMAN 10 Aceh Barat Daya. Skripsi. Universitas Islam NegeriArRaniry Darussalam. Banda Aceh

Nuraeni, N. (2010). Efektifitas Penerapan Model Pembelajaran Generative Untuk Meningkatkan Pemahaman Siswa Dalam Mata Pelajaran Teknologi Informasi dan Komunikasi. Skripsi (tidak diterbitkan). Bandung: UPI

Suryosubroto, B. (2009). Proses Belajar Mengajar di Sekolah. Jakarta. PT Rineka Cipta 